\title{
Assessing and forecasting the impacts of global change on Mediterranean rivers. The SCARCE Consolider project on Iberian basins
}

\author{
Alícia Navarro-Ortega • Vicenç Acuña • Ramon J. Batalla • Julián Blasco • \\ Carlos Conde · Francisco J. Elorza • Arturo Elosegi • Félix Francés • \\ Francesc La-Roca • Isabel Muñoz • Mira Petrovic • Yolanda Picó • Sergi Sabater • \\ Xavier Sanchez-Vila • Marta Schuhmacher • Damià Barceló
}

Received: 3 March 2011 / Accepted: 27 June 2011

(C) Springer-Verlag 2011

\begin{abstract}
Introduction The Consolider-Ingenio 2010 project SCARCE, with the full title "Assessing and predicting effects on water quantity and quality in Iberian Rivers caused by global
\end{abstract}

Responsible editor Thomas Braunbeck

A. Navarro-Ortega $(\bowtie) \cdot D$. Barceló

IDAEA-CSIC,

Jordi Girona, 18-26,

08034 Barcelona, Spain

e-mail: alicia.navarro@idaea.csic.es

V. Acuña $\cdot$ M. Petrovic $\cdot$ S. Sabater $\cdot$ D. Barceló

ICRA, Edifici H2O,

Emili Grahit, 101,

17003 Girona, Spain

R. J. Batalla

UdL/CTFC,

Alcalde Rovira Roure 191,

25198 Lleida, Spain

J. Blasco

ICMAN-CSIC,

Campus Rio San Pedro,

11510 Puerto Real, Cádiz, Spain

C. Conde $\cdot$ F. J. Elorza

UPM,

Avda. Ramiro de Maeztu 7,

28040 Madrid, Spain
A. Elosegi
UPV/EHU,
Barrio Sarriena $\mathrm{s} / \mathrm{n}$,
48940 Leioa, Spain
F. Francés
UPV,
Camino de Vera s/n,
Valencia, Spain

change" aims to examine and predict the relevance of global change on water availability, water quality, and ecosystem services in Mediterranean river basins of the Iberian Peninsula, as well as their socio-economic impacts. Starting in

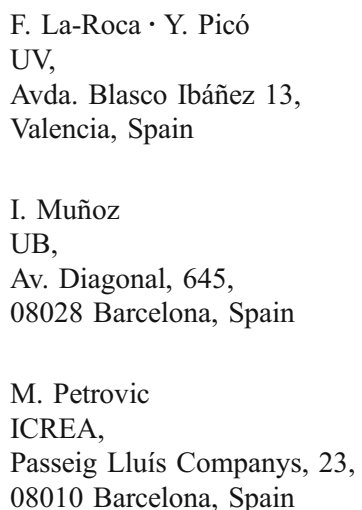

S. Sabater

UdG, Institute of Aquatic Ecology,

Campus Montilivi,

17071 Girona, Spain

X. Sanchez-Vila

UPC,

Carrer Jordi Girona 31,

Barcelona, Spain

M. Schuhmacher

ETSEQ, URV,

Campus Sescelades,

43007 Tarragona, Spain

D. Barceló

King Saud University,

Box 2455, 11451 Riyadh, Saudi Arabia 
December 2009, it brought together a multidisciplinary team of 11 partner Spanish institutions, as well as the active involvement of water authorities, river basin managers, and other relevant agents as stakeholders.

Methods The study areas are the Llobregat, Ebro, Jucar, and Guadalquivir river basins. These basins have been included in previous studies and projects, the majority of whom considered some of the aspects included in SCARCE but individually. Historical data will be used as a starting point of the project but also to obtain longer time series. The main added value of SCARCE project is the inclusion of scientific disciplines ranging from hydrology, geomorphology, ecology, chemistry, and ecotoxicology, to engineering, modeling, and economy, in an unprecedented effort in the Mediterranean area. The project performs data mining, field, and lab research as well as modeling and upscaling of the findings to apply them to the entire river basin.

Results Scales ranging from the laboratory to river basins are addressed with the potential to help improve river basin management. The project emphasizes, thus, linking basic research and management practices in a single framework. In fact, one of the main objectives of SCARCE is to act as a bridge between the scientific and the management and to

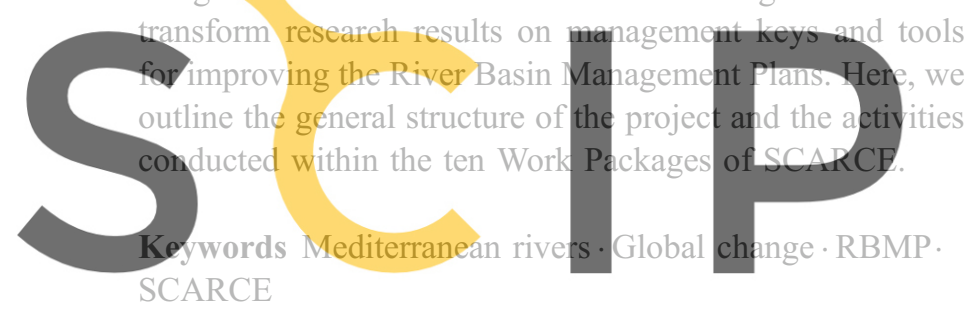

Register for free at https//www.scipedia.com to 1 Introduction

The Mediterranean basin is one of the world's regions most vulnerable to global change (Barceló and Sabater 2010) and one of the "hot spots" for oncoming problems in water availability (Giorgi and Lionello 2008). Current climate change models forecast that the Mediterranean region will likely register increased summer drought and stronger rainfall events (IPCC 2007); thus, average river discharge is predicted to decrease and water temperature and the frequency of large floods to increase (Calbó 2010). Low summer flow and large floods in autumn and winter are characteristics of rivers under Mediterranean climate (Gasith and Resh 1999), but the forecasted scenarios suggest several points of concern, including decrease hydrological connectivity and increase in the concentration of pollutants during droughts, changes in biological communities as a result of harsher environmental conditions, and a decrease of biological processes like nutrient uptake, primary production, or decomposition. Furthermore, the increased pressure on shrinking water resources will compound the impacts on river ecosystems (Sabater and Tockner 2010).

Since freshwater ecosystems deliver important services to society (Millenium Ecosystem Assessment 2005), such as supply of water and waste treatment, water scarcity affects both the ecosystems and human beings, especially in semi-arid areas like the Mediterranean region where it becomes a major constrain for the socio-economic development. Rising pressures on water resources result from socio-economic activities of growing human population and include changes in land use or the large number of dams and reservoirs (Tharme 2003). The extent of river regulation increases steadily in the Mediterranean region, resulting in extensive river segments which become disconnected from each other (Nilsson et al. 2005). The imbalance between the available water resources during extended droughts and the increasing anthropogenic water demand results in acute environmental and socio-economic problems. In consequence, water availability and also its temporal variability, quality, and the survival of ecosystems associated to water bodies, has become a major issue for all Mediterranean regions

Within this context, SCARCE is a research project that

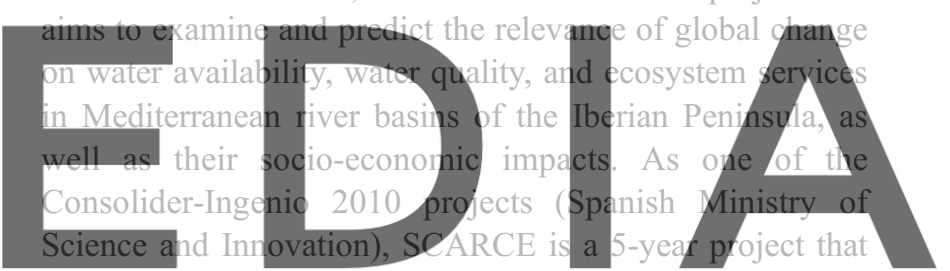

has been active since December 2009. The project has the full title of "Assessing and predicting effects on water download the versipn without the watermark

change". The consortium assembles a multidisciplinary team of 11 partner Spanish institutions, as well as the active involvement of water authorities, river basin managers, and other relevant agents as stakeholders. Scientific management of the project is carried out by the Institute of Environmental Assessment and Water Research of the Spanish Council for Scientific Research of Barcelona. The project integrates various disciplines that range from hydrology, geomorphology, ecology, chemistry, and ecotoxicology, to engineering, modeling, and economy, in an unprecedented effort in the Consolider-Ingenio 2010 framework.

SCARCE has two complementary objectives. The first one tackles basic research questions and will attempt to define the long-term patterns and the mechanisms that operate in the hydrology, sedimentary processes, water quality, habitat dynamics, and ecosystem structure and functioning of Mediterranean basins. The second objective is related to the effects of climate and human footprint on the ecosystem services of selected river basins. This is connected to the urgent need to implement and eventually 
redefine the River Basin Management Plans (RBMP) demanded by the EU Water Framework Directive. Therefore, the project emphasizes linking basic research and management practices in a single framework.

\section{Study basins}

SCARCE applies a multidisciplinary cross-scale approximation combining data mining with field-based research in four representative basins in Spain: Llobregat, Ebro, Júcar, and Guadalquivir (Fig. 1). These basins cover a substantial area of the Mediterranean Iberian Peninsula, as well as a rich set of socioecological conditions: forested mountain areas, highly populated basins, agricultural regions, and industrial clusters depending on groundwater resources. These four basins were not only selected for their characteristics but also considering their previous inclusion in other European and national projects. This fact increases the amount of data available and allows a better and more detailed study of the river processes.

The Llobregat River (NE Spain) is $156 \mathrm{~km}$ long and drains a $4,957 \mathrm{~km}^{2}$ catchment. From the hydrologic point of view, this is a typical Mediterranean river, its flow being highly variable as a result of seasonal differences in rainfall. Periodic floods and droughts lead to frequent morpholog-
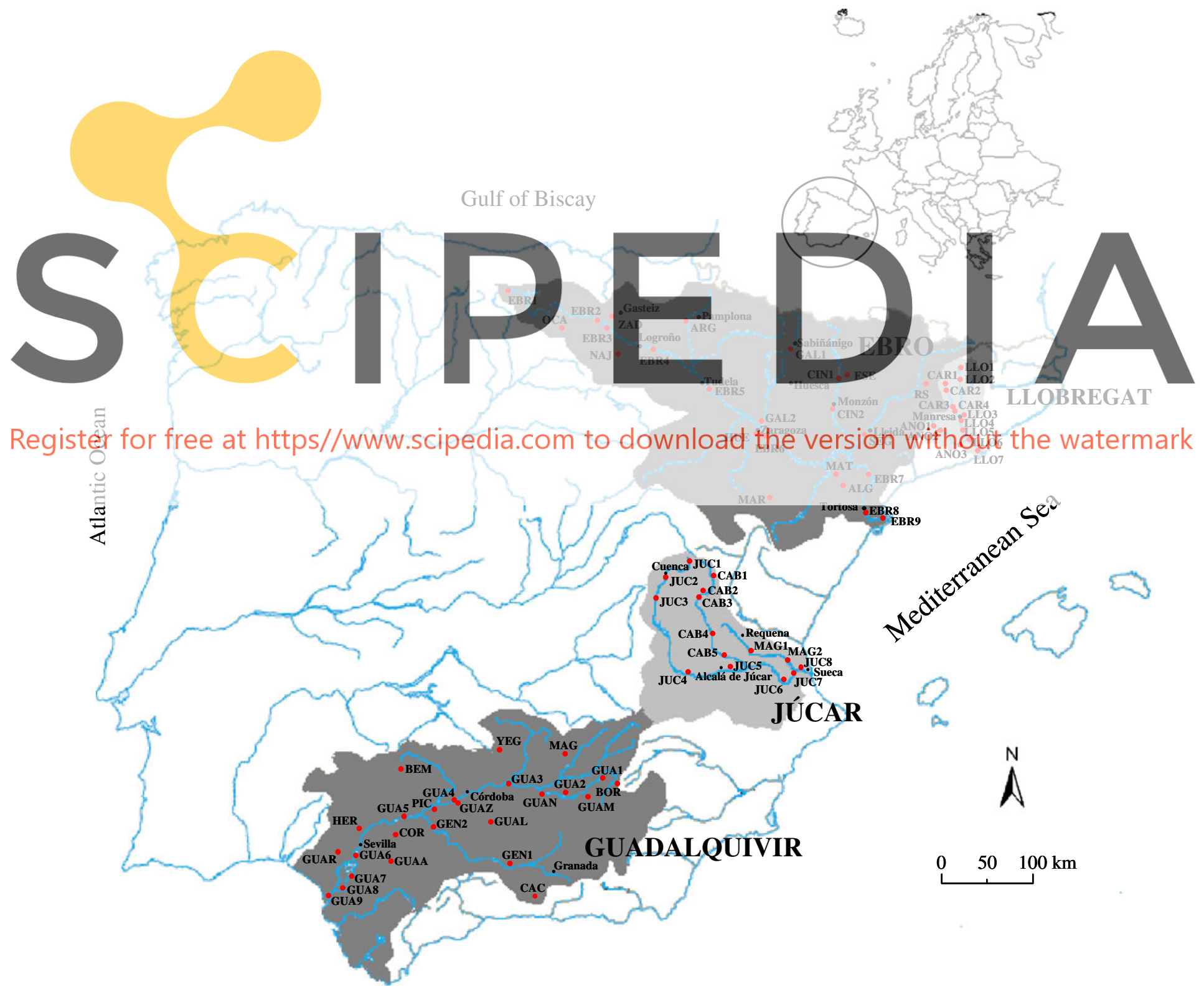

Fig. 1 The four River Basins (Ebro, Llobregat, Júcar, and Guadalquivir) studied in SCARCE with indication of monitoring sites 
ical variations in the riverbed. Its basin is heavily populated with more than three million inhabitants. This river is one of Barcelona's major drinking water resources. Together with its two main tributaries (rivers Cardener and Anoia), the Llobregat suffers a heavy anthropogenic pressure, receiving extensive urban and industrial wastewater discharges as well as surface runoff from agricultural areas that cannot be diluted by its natural flow. Consequently, waters have high concentration of nutrients, pesticides, surfactants, pharmaceuticals, and estrogenic compounds with important effects on the biological communities (Muñoz et al. 2009; Ricart et al. 2010b). During droughts, dilution capacity decreases, increasing the risk of pollutants in the environment, which might affect the functioning of the river ecosystem. Main watercourses are regulated by three large dams that impound around 35\% of the basin's mean annual runoff. Further downstream, the river receives brine leachates from natural salt formations and mining operations, which have caused a chronic increase in water salinity downstream. The river is heavily managed in its lower course and water that once run to the sea is now pumped upstream to increase the natural flow, recharge the delta wetlands and control seawater

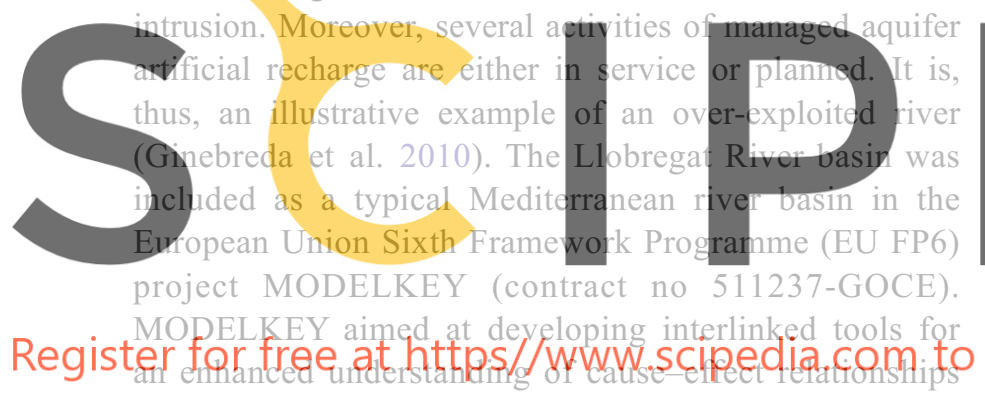

between poor ecological status and environmental pollution (Brack et al. 2005).

The Ebro River is $910 \mathrm{~km}$ long and drains an area of $85,534 \mathrm{~km}^{2}$, from North Central to NE Spain. It has a complex hydrological regime, as it receives water from tributaries under contrasting climates, from snow-fed Pyrenean Rivers to more typical Mediterranean tributaries in the southern part of the basin. Despite its much larger size, the Ebro basin has a smaller population than the Llobregat, some 2.7 million inhabitants, of which $45 \%$ live in the five biggest cities in the region (Navarro et al. 2006). Most of the Ebro Basin is agricultural land, making it one of the most irrigated areas in Spain, but lately industry has been a growing sector (CHE 2008; Navarro et al. 2010). A feature of interest is the Ebro delta, as it hosts both intensive agricultural areas where rice, fruit (in particular citrus), and vegetables are harvested, as well as the Ebro Delta Natural Park, one of the most important coastal wetlands in the Western Mediterranean region. The Ebro is largely regulated by dams (187 dams with a global impoundment ratio of $67 \%$ ) and channels, which have altered its hydrological and sedimentary regime. During the twentieth century, the mean annual flow decreased by approximately $30 \%$, due to increased irrigation, evaporation from reservoirs, and extensive changes in soil uses. Sediment yield is currently $1.5 \%$ of the estimated before dam construction and extensive land use changes took place (Vericat and Batalla 2006). Abstraction of ground and surface water, irrigation, and industrial activities concentrated close to the main cities have also deteriorated soil and water quality, where pollution caused by organic compounds is relevant. The inclusion of the Ebro river basin into the EU FP6 project AquaTerra (contract no. 505428) led to an extensive monitoring of persistent organic pollutants (Lacorte et al. 2006). A comprehensive 4-year monitoring program was conducted in order to assess the levels of contaminants in the Ebro river basin and to evaluate their environmental risk (Navarro-Ortega et al. 2010). In addition, the fate and behavior as well as the risk caused by a broad spectrum of emerging contaminants like pharmaceuticals, illicit drugs, brominated flame retardants, and polar pesticides were investigated in the Ebro river basin throughout the project, from 2004-2009. This information together with ecological and hydrological

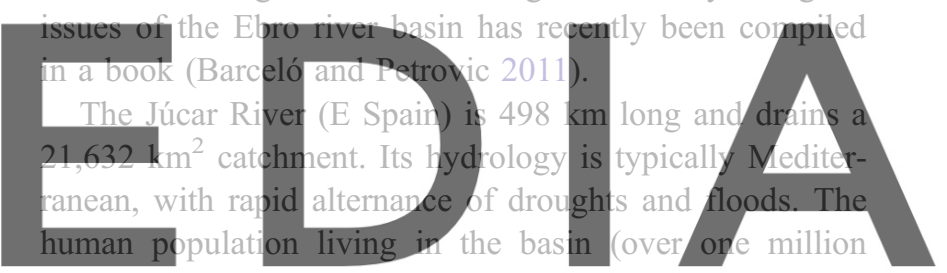
people) makes an intensive use of the available water, the demand being pften in excess of water supply (Estrela et al downl qad the versipn without the waternark

water demand $\left(1,394 \mathrm{hm}^{3} \mathrm{y}^{-1}\right.$ for 200,000 ha of irrigated crops), but agricultural demand appears to be stabilized or decreasing, whereas urban/industrial demand is forecasted to rise (Estrela et al. 2004; Paredes-Arquiola et al. 2010). The Júcar is highly regulated, with a total reservoir capacity of $2,643 \mathrm{hm}^{3}$. The management of the system is very complex, with many users and considerable hydrologic variability. Water quality problems appear in the medium and lower parts of the basin. In the medium part, agriculture leads to high nitrate concentrations in groundwater and surface water, whereas in the lower part there is a combination of agriculture, urban, and industrial pollution (Paredes-Arquiola et al. 2010). Furthermore, groundwater overextraction has unbalanced the hydrological system, severely affecting the river flow, and causing water scarcity and salinisation of the mouth of the river. Nowadays, periods of zero flow into the sea are common, and marine intrusion is producing a salt wedge of more than $3 \mathrm{~km}$ long. The Júcar drains to the Albufera de Valencia, a large coastal lagoon, and an important protected wetland. The Júcar basin was designated as a European Pilot River Basin 
(PRB) for the implementation of the Water Framework Directive. The Júcar PRB exercise started at the end of 2002 and since then, much of the information concerning the current status of the basin has been analyzed (Estrela et al. 2004).

The Guadalquivir River (S Spain) is $657 \mathrm{~km}$ long and drains a $57,527 \mathrm{~km}^{2}$ catchment. The entire basin is under a Mediterranean climate, receiving some influence from the Atlantic Ocean in the lowest part. Summer droughts are especially severe as a result of high temperature and lack of rain. More than seven million people live in the basin, $60 \%$ of them in cities, and $30 \%$ of urban and industrial sewage is poured untreated into the Guadalquivir (Martín et al. 2010). More than 700,000 ha of the basin are devoted to agriculture, with very extensive production of rice, olives, or fruits. As a consequence of agricultural, urban, and industrial uses, water pollution is common along the middle and low reaches of the Guadalquivir. Furthermore, the river is heavily regulated, $26 \%$ of the total volume of water within the entire basin being stored in reservoirs (Martín et al. 2010), especially for agricultural purposes ( $85 \%$ of the demand). The river is navigable up as far as Seville (a major inland port about $90 \mathrm{~km}$ upriver), producing serious
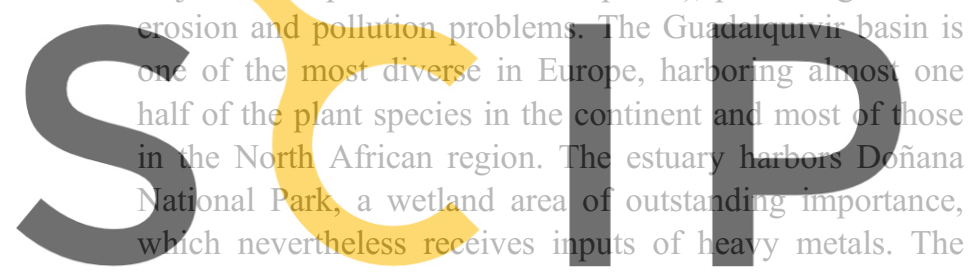

Guadalquivir River has been lately included in several EU

Regijects: AQUAMQNEY (contract no. S.SP1-0.022723) and

RegisteKfor free at https//www.scipedia.com to

An extensive network of 77 sampling sites has been established in the four selected river basins. These sampling sites do not only cover the most impacted areas, for chemical, hydrological, morphological, and ecological analysis but also reference sites in the river sections in which best quality is expected. All the field studies that will be performed among the different Work Packages (WPs) will consider all or some of these sampling sites. The basic research element of the field-based study is the kilometerscale river reach, including the river channel, the alluvial plain, and associated groundwater, as well as the river reaches downstream from dams. At this scale, we are evaluating the impacts of global change on several processes affecting freshwater ecosystem services (e.g., nutrient processing and contaminant retention, sediment transport, community assembling, and habitat integrity). Results will be upscaled from the river basins studied to the whole Mediterranean region in Spain using different mathematical models. Information of the project is regularly updated and available at the SCARCE Website (http://www. idaea.csic.es/scarceconsolider).

\section{The structure of SCARCE}

SCARCE is structured across ten thematic WPs that coordinate the various scientific goals (Fig. 2). The WPs deal with data collection (WP DATA), hydrology (WP HYDROL), sediment transport, and river channel morphology (WP MORPH), chemical and biological quality (WP QUALITY), ecosystem processes (WP PROCESS), modeling (WP UPSCALE), socio-economic scenarios (WP ECONOMY), ecosystem services (WP SERVICES), river management (WP FRAME), and coordination (WP MANAGE). All of them can be classified in one or more of the three defined main topics (data mining, field and lab research, or upscaling and integration). Exceptions are WP MANAGE, which deals with the project coordination, dissemination and training activities, and WP FRAME, whose main objective is the transfer of all the findings to the stakeholders and policy makers for its future application in the management of the river basins. Among all of them, the Scientific Steering Committee coordinates and monitors the progress of the work carried out in each research line and the External Advisory Committee ensures social and political feasi-

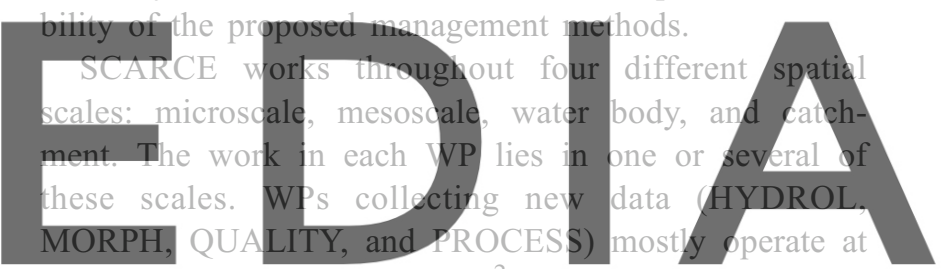
micro- and mesoscales (from $\mathrm{m}^{2}$ to $\mathrm{km}$ reach). Other WPs (UPSCALE, ECONOMY, SERVICES, and FRAME) downlqad' the version without the waternark

(water body to catchment, Fig. 3).

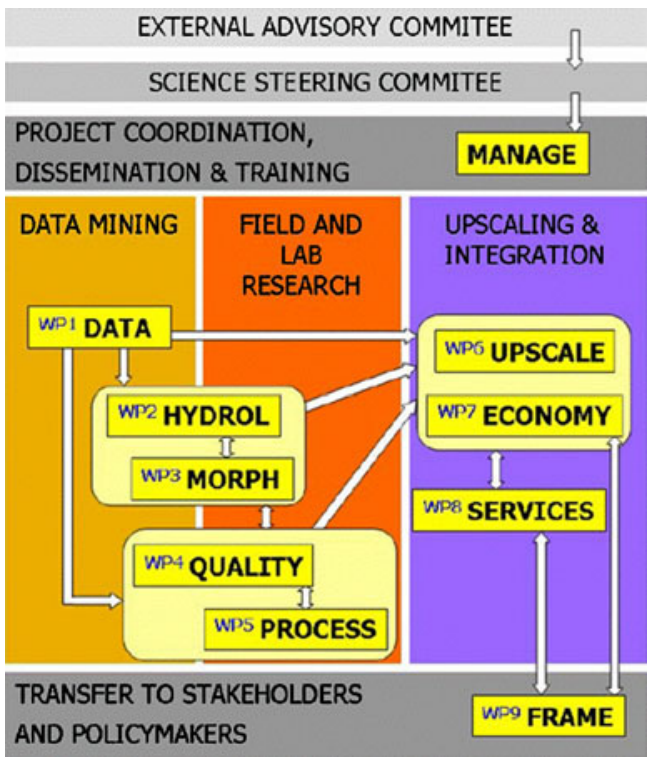

Fig. 2 SCARCE project structure and interaction between WPs 
Fig. 3 SCARCE project structure in relation to working scales (see Fig. 2 for details on the interrelation between Work Packages)

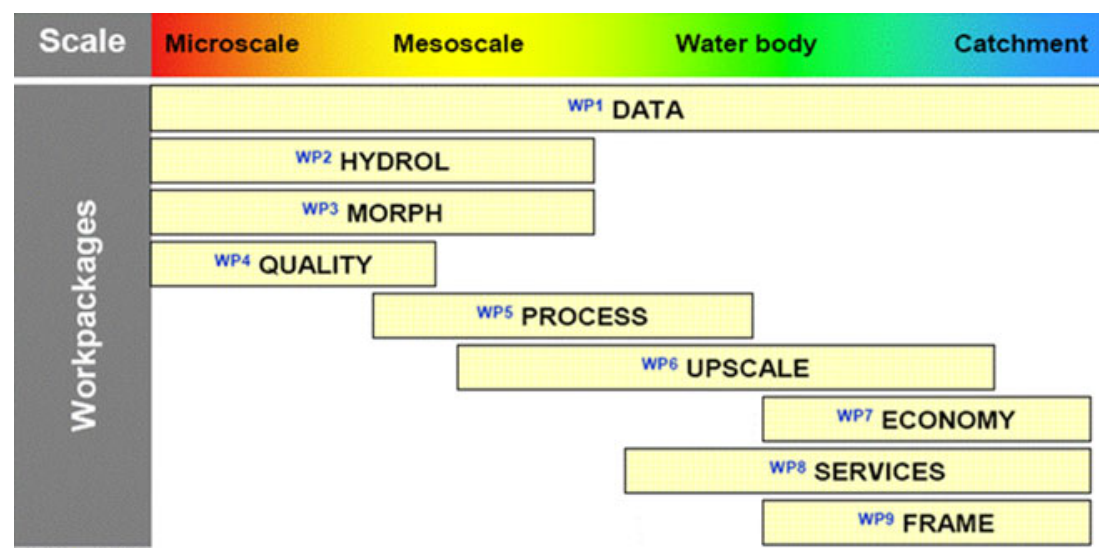

WP DATA attempts to gather in a common framework long-term observations of hydrology, water quality, sediment transport, biological communities, society, and economy, available in the four study basins to build a standardized database, which is an essential tool for this type of consortium (Lindenmayer and Likens 2009). For this purpose, research teams participating in WP HYDROL, MORPH, QUALITY, and PROCESS are working together with the water agencies and firms

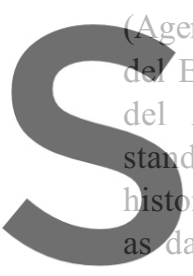
encia Andaluza del Agua, Con te Agua, and Aguas de Barcelona dardize a vast database. orical and present data taken research teams. The data so gathered will be analyzed for temporal trends, and spatial patterns at the regional scale

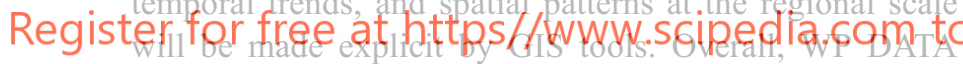
provides an assessment of global change effects on Iberian rivers and assists WP UPSCALE, PROCESS, and SERVICES in detecting adequate hot spots to be used as calibration sites for models simulating key river ecosystem processes. This WP also checks for climate and global change effects in studied basins following the IPCC attribution guidelines (Weyhenmeyer 2004). The results obtained will feed different research needs across WPs.

WP HYDROL approaches the interactions between surface water and groundwater, especially those occurring from centimeters upwards to microscale ( $\mathrm{cm}$ to $\mathrm{m}$ ). These interactions are important because although aquifers can become crucial reservoirs to supply water for drinking, agricultural, industrial, or ecological purposes, this function can compromise processes occurring at these interfaces. For instance, sediments occurring in dams might release compounds that affect the biota. Therefore, WP HYDROL in collaboration with WP MORPH analyzes the impact of the interaction between water and sediments accumulated in dams, river beds, and infiltration ponds on water quality in the study basins. It also characterizes the effects of artificial recharge operations on water quality in one specific site (the Llobregat basin), together with WP QUALITY. Artificial recharge has become an attractive tool for sustainable water management practices since groundwater reservoirs are widely available, unaffected by evaporation losses and requiring moderate infrastructures (Greskowiak et al. 2005). But the impact of artificial and induced recharge on water quality is largely unknown. Finally, this WP determines the likelihood of chemical compounds to

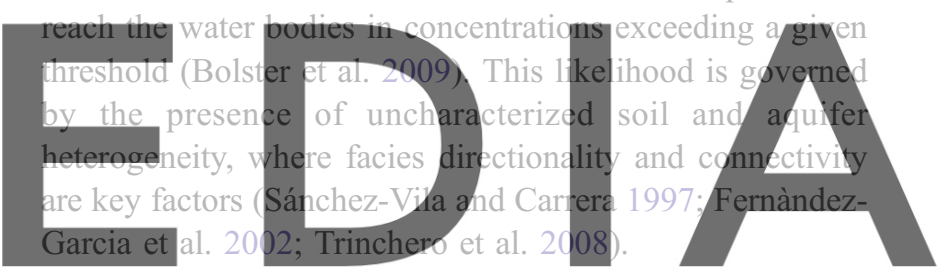

WP MORPH examines the main morphosedimentary processes in selected river reaches from the micro to the downlgad the version without the waternark

for physical habitat in a series of scenarios of change. New baseline data are provided, and insights on river dynamics will be helpful to ongoing and updated RBMP. Special emphasis is placed on the analysis of impacts of river regulation onto sediment transfer (direct relation to WPs QUALITY and PROCESS) and their implications for the downstream sediment budget and channel morphodynamics and sedimentology (Singer and Dunne 2001; Vericat and Batalla 2006). Data are used to assess the sediment load at various temporal scales (e.g., flood and seasonal), sediment transport regimes (e.g., frequency and magnitude and variability of yields), quantitative assessment of sedimentary status (e.g., grain-size distribution and riverbed structure and stability) and channel morphology (e.g., hydraulic geometry and pool-riffle sequence) and the design of an index of morphosedimentary change. Data will feed a model of sediment transport regimes under changing hydroclimatic scenarios that will be developed by WP UPSCALE.

WP QUALITY determines the presence and concentration of priority and emerging contaminants in the four 
selected river basins from the Iberian Peninsula. The effects of pollutants on the biota (algae and bacteria, macroinvertebrates, and fishes), and the interactions between pollution and water scarcity, are assessed by combining field surveys and laboratory experiments, looking at biodiversity patterns and toxicity tests under environmental stress (Guasch et al. 2009; Muñoz et al. 2009). The effects of multiple stressors are addressed from a multi-biomarker perspective, including structural (chlorophyll $a$, EPS, community composition, etc.), and functional (photosynthesis, enzymatic activities, etc.) descriptors. Results are feeding the understanding of WP PROCESS and together with those of WPs DATA, HYDROL, and MORPH contribute to form the basis of WPs UPSCALE, SERVICES, and FRAME. The potential human health risks in the river basin are assessed through mathematical approaches, crucial to provide a suitable decision making to stakeholders (Nadal et al. 2008). "Intelligent Testing Strategies" will be applied for a large number of chemicals to assess the risk of appearing in a given water body. Finally, the potential effects of global change in ecosystems and humans, in terms of risk assessment, will be upscaled by modeling tools connected with the WP UPSCALE.

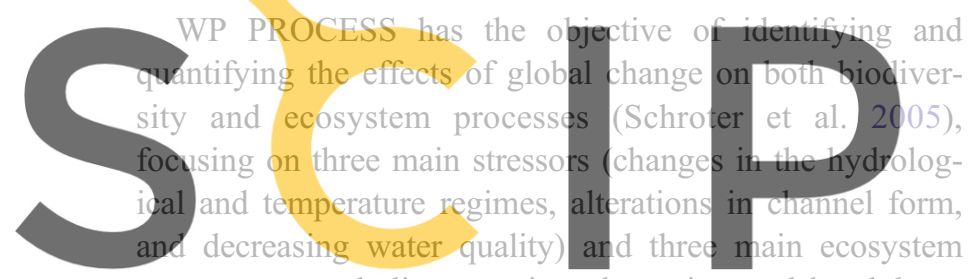
processes: metabolism, nutrient dynamics, and breakdown of organic matter. For example, the duration of floods after Register far free at https flyww scipediacom to stream beds (Sand-Jensen and Pedersen 2005). Very short flood pulses (typical in flashy urban streams) release nutrients, thus increasing in-stream productivity in adjacent reaches. Hence, the relative extent and the dynamics of the temporary channel network, as well as its spatial distribution within a catchment, may influence the capacity of an entire river network to produce, transform, and store nutrients and organic matter. These changes can be understood combining on-site analysis, mesocosmos analysis, and upscaling of relevant processes occurring in river segments, which should be related to the variations in hydrology, water chemistry, and sediment dynamics. To assist this process, WP PROCESS combines and develops tools to assess the effects of global changes in streams and rivers, and evaluates effects of disturbances on nutrient cycling and metabolism of Mediterranean stream and rivers, by using a space-by-time design on the sites analyzed. This WP will provide results to the WP UPSCALE through the development of the mechanistic model.

WP UPSCALE uses mathematical models to extrapolate the state variables of interest from observations to scenarios of global change. It also builds and tests a series of deterministic and statistical models devoted to simulate hydrological, geomorphological, chemical, and ecological processes in the basins under study. Therefore, this WP is directly connected with most other workpackages: it is fed with information and data from WP DATA, it uses mesoand water body scales, as well as new conceptualizations of the processes involved (from WPs HYDROL, MORPH, QUALITY, and PROCESS), and it will assist the models applied in WP SERVICES (with input data series and water body conceptualizations). Two different sets of models are used in WP UPSCALE, namely process oriented and system oriented. The proposed process-oriented models are distributed in space to cope with the natural spatial variability of the water cycle within the catchment. New hydrological modeling capacities of the rainfall-runoff model TETIS (Francés et al. 2007) are built in order to deal with climate and environmental changes affecting the water cycle as well as associated processes. The systemoriented models are defined at the river network (water body scale) and take into account the integration of the water cycle into the management of water resources at the catchment scale in Decision Support Systems (DSSs)

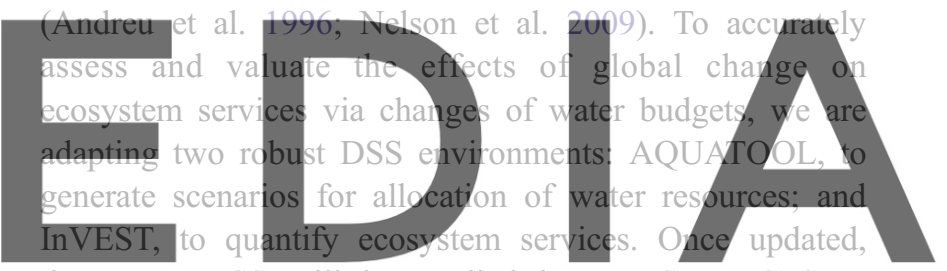
these two DSS will be applied in WP SERVICES to evaluate alternatives, and. to analyze planning decisions in dowdhad the kersion without the watermark

WP ECONOMY approaches the economic assessment of ecosystem services, and describes the likely socioeconomic scenarios for future conditions. Humans derive important services from ecosystems, but at the same time, human activities may impact ecosystem functioning (Millenium Ecosystem Assessment 2005). Although human well-being obviously depends on healthy ecosystems, this fact is not fully reflected by the economic system. The price mechanisms governing markets ignore the goods and services provided by ecosystems which are not traded. The main methodological question addressed by the WP ECONOMY is how to estimate the relevance of ecosystem services for the economic organization of human societies. Ecosystem services identified in cooperation with WP SERVICES are classified under economic criteria in market traded and non-market provided. Services grouped under the first label can be partially valued in monetary terms, and are currently perceived as commodities by economic agents. On the opposite, non-market services despite their sometimes crucial relevance for the ecosystem and ultimately for human survival- are neglected by 
the economy. The value of these services can be only partially approached through indirect monetary assessments, like the cost to restore damaged ecosystem functioning or the cost of an artificial alternative (if it exists). Other more comprehensive ways of trying to confront the incommensurability of these valuation problems include: the use of multicriteria assessments with different metrics of value, and the use of social deliberative processes that go well beyond quantitative. When the analysis period grows longer, as it is the case of the SCARCE project, the information provided by prices becomes banal. For this reason, a relevant topic in WP ECONOMY is to analyze the different types of uncertainty involved in the valuation exercise and to propose methods to best deal with it, in the mid- and short run.

WP SERVICES aims to quantitatively assess ecosystem services in river networks and associated wetlands, providing decision support for integrated RBMP (Nelson et al. 2009). This WP models and maps the delivery, distribution, and economie value of ecosystem services (Dodds et al. 2009) and, thus, helps users to visualize the impacts of potential decisions, identifying tradeoffs, and compatibilities between environmental, economic, and social benefits.
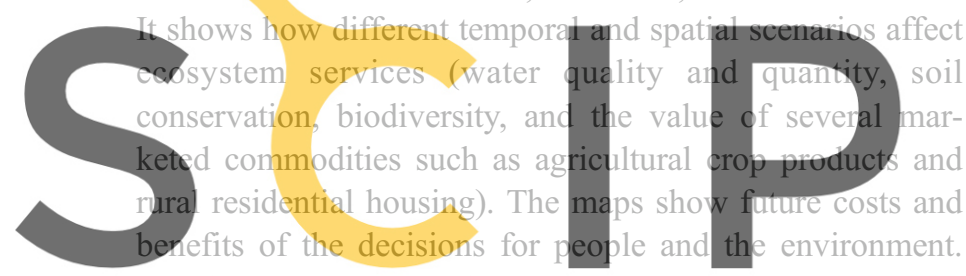

For the integration in the RBMP, two types of DSSs, the ones developed with Aquatool and InVEST, are used to

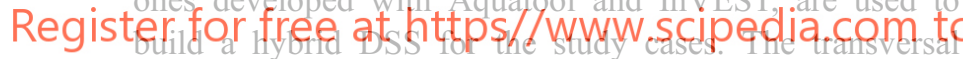
component of WP SERVICES within SCARCE requires to be closely related to DATA, QUALITY, PROCESS, UPSCALE, ECONOMY, and FRAME. Thus, long-term data series gathered by DATA (hydrology, geomorphology, and chemistry), and QUALITY (biodiversity and human risk) are feeding the model; PROCESS provides a mechanistic functioning; UPSCALE supplies the tailored DSSs with appropriate mechanistic model of ecosystem functioning and supplies data on future climate change scenarios based on downscaling Global Climate Models; ECONOMY assists SERVICES with economic analysis of ecosystem services, and FRAME interacts with policy makers and stakeholders in order to work with realistic and targeted socio-economic scenarios.

WP FRAME fills the gap between research and management and aims to transform research results on management keys and tools. A two-way complementary process of knowledge transfer, connecting science and management practice is necessary, and is implemented in this WP through the use of a management and regulatoryoriented language, thus bridging the presently existing communication gap between scientists and water managers/authorities. The main purposes of this WP are to identify new research needs under the light of the Water Framework Directive (Directive 2000/60/EC), to transform research results on management options and to provide sound scientific assessment to the forthcoming RBMP and the related Programs of Measures (PoMs). Work-Package FRAME has an intrinsic "horizontal" character, working as an interface between the other WPs and the managers or end-users, and its scope is essentially communicationoriented. Interactions with WPs ECONOMY, SERVICES, and MANAGE are particularly emphasized. From each WP, key questions or issues are generated from the scientific side or, conversely, compiled after assessing the management needs. These are conveyed by workshops and meetings with representatives of the water boards involved in the project. This exercise will ultimately lead to a check list or catalogue of relevant issues. The contents of those management outputs, tailored to each particular river basin, should be presented, discussed, and, if possible, agreed with the respective water managers/authorities, through appropriate knowledge diffusion actions (workshops, working sessions, etc.). The expected added value should be its

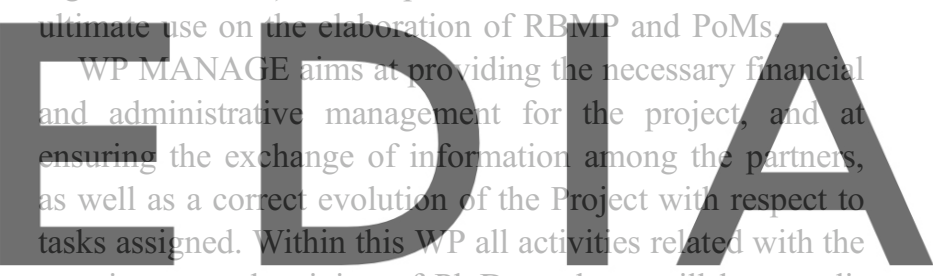

recruitment and training of Ph.D. students will be coordinated as well as the dissemination aptivities aimed to ensure download the version witheut the watermark

scientific community and socio-economic sectors, and regulatory bodies involved in water Management such as river basins and water authorities.

\section{Work undertaken so far}

Under WP DATA, contacts with water agencies have been established and data are being collected in all the basins and pre-treated, and a common database is being configured for the consortium. Data collected include water quality (both chemical and biological parameters), hydrology (long data series across the basins) and cartographic information (land uses, impacts, and flooding areas). Currently, nutrient data in the Llobregat River (from 2000 to 2006) are being analyzed in order to apply a Spatially Referenced Regression Model to estimate nutrient sources related to land uses. A user-friendly database is now designed in order to compile from each basin basic historical data and the new data generated during the project duration. This database will also offer specific information (webs and documents) 
about the location of the complete data available in each basin. Several climatic change (CC) scenarios (meteorological and hydrological) have already been analyzed, processed, and used in different studies. Moreover, new climatic regional scenarios provided by the Spanish Meteorological Agency will be taken into account to generate new hydrological scenarios in order to analyze several impacts at the Júcar River basin. Contacts with other national institutions (Centro de Estudios y Experimentación de Obras Públicas, CEDEX) have been done to adapt their scenarios of climate change to the SCARCE objectives. CEDEX is currently downscaling different general climatic models to a $1-\mathrm{km}^{2}$ scale, and these results will be used to generate improved hydrological scenarios with TETIS-SCARCE.

WP HYDROL deals with processes taking place at a small to medium scale. At this point emphasis has been placed on hydro- as well as geo-chemical characterization in saturated soils/sediments. The fate of contaminants (both inorganic and organic) is driven by a number of processes. Among them, work has been performed along different lines. First, local-scale diffusion is causing chemical elements to interact. The amount and rate of interaction depends on the ability of reactants to mix. Laboratory experiments in 2D tanks aimed at characterizing the an ount of mixing caused by temporal yar been developed. It has been yarigtions do indeed enhance inix rally enough to consider variable pumping as a competitive method for remediation. On the other hand, it is true Register for frewa wh would eventually reach different areas of this has strong implications in the variations in chemical signature of water along the percolation path, it is not obvious how this affects the degradation of micropollutants.
A number of batch tests have been carried out under controlled batch conditions to evaluate whether different micropollutants degrade under given redox conditions. This has allowed classifying the substances depending whether or not they degrade under specific redox conditions. Finally, a probabilistic approach to evaluate the potential risk of hydrological practices related to water supply systems based on the use of fault trees has been devised. Fault trees allow decomposing the assessment of health risk into individual manageable modules. The complexity within each module can be chosen individually according to data availability, parsimony, relative importance, and stage of analysis. The separation in modules allows for a true inter- and multidisciplinary approach, where different expert can take care of the different modules and the integration is externally performed by the fault tree. A traditional limitation of fault tree approaches is the need for the different sub-modules to be independent or weakly dependent. The need for this hypothesis has been weakened. Finally, total probability of system failure can be updated whenever additional information is incorporated into the system. This can be done by means of Bayesian analysis, which allows providing a posterior risk assess-

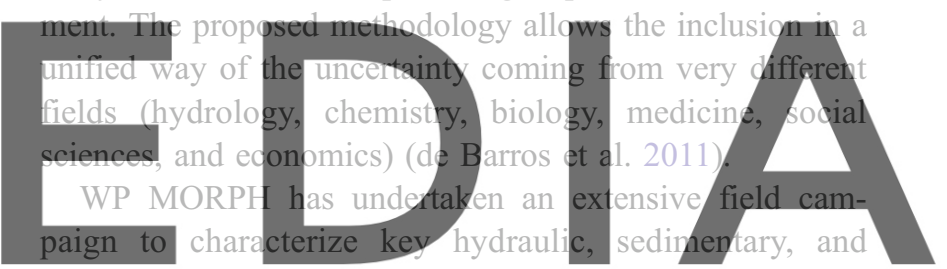

vegetation parameters at the 77 selected sites along the dour representative basins.(details. in Fig. 1) Reach length is sequence). Measurements have been undertaken on grainsize distribution of riverbed materials, i.e., including both surface (Fig. 4) and subsurface sediments to identify river
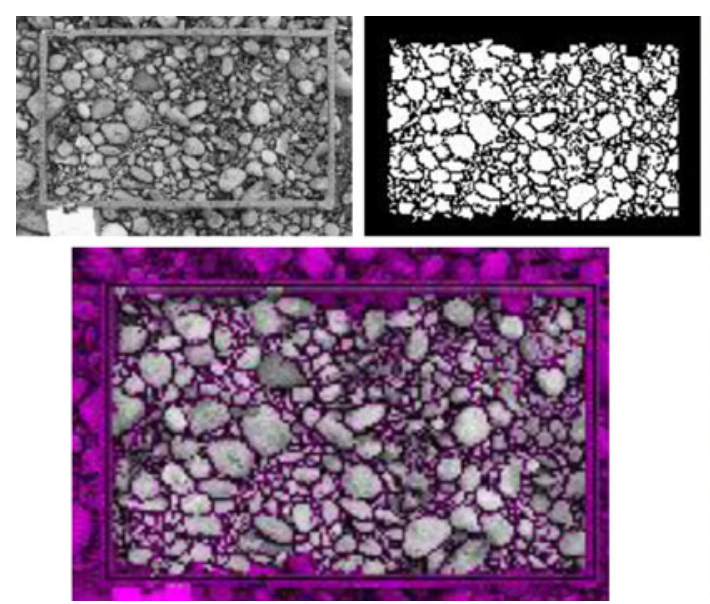

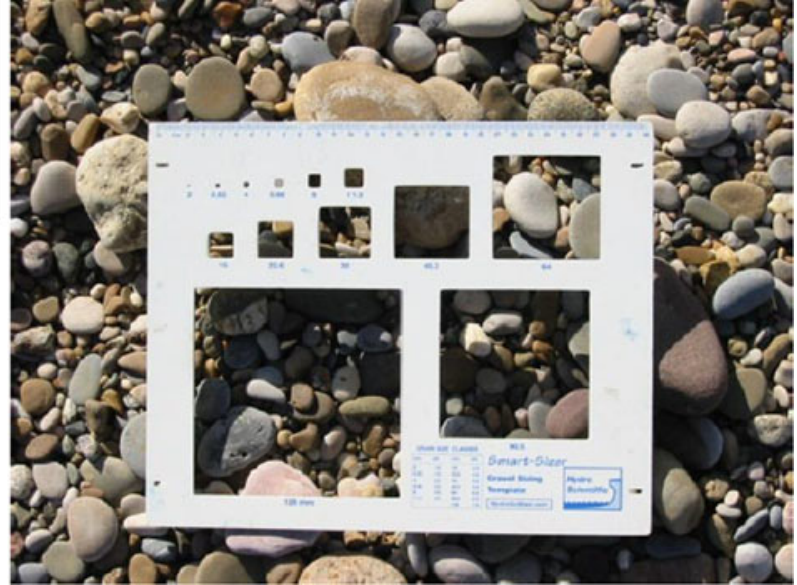

Fig. 4 Left, example of grain-size identification and particle measurement by means of the Digital Gravelometer ${ }^{\mathbb{R}}$; right, template used during particle counts for surface sediments (figure prepared by D. Vericat and extracted from the WPs MORPH/PROCESS field protocol) 
armouring and hence stability, and patches of fine particles (a total of 3,000 particles and $500 \mathrm{~kg}$ of material have been sampled and processed in the first fieldwork round). Grainsize parameters are also assessed by means of close-range photographies that are further analyzed with a Digital Gravelometer ${ }^{\circledR}$ (Loughborough University Enterprises Limited, Leicestershire, UK) (Fig. 5). Largest moving particle is also measured to assess flow competence at the section. Observations on channel incision and sedimentsupply limitation are also taken. Hydraulic geometry is established based on measurements of channel cross section and longitudinal gradient; these data are obtained by means of a Geodimeter ${ }^{\circledR} 422$ Total Station (Geotronics AB, Danderyd, Sweden) and a Leica ${ }^{\circledR}$ TCRP1201 Robotic Station (Leica Geosystems, St. Gallen, Switzerland). A total of 150 cross sections have been surveyed. Data will be used to derive information of the active and bankfull channel and associated flow depth and shear stress by means of hydraulic modeling with WinXSpro ${ }^{\circledR}($ Stream Systems Technology Center, Fort Collins, Colorado, USA). Velocity profiles are also obtained which will also be later used to derive flood and representative habitat discharges with Hec-Ras ${ }^{\circledR}$ (Institute for Water Resources

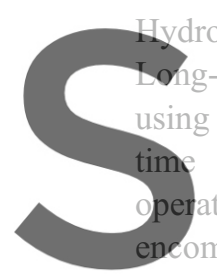
-term changes of piver mar the analysis of available ain span ranging from the ating sediment transport an mpassing selected sites
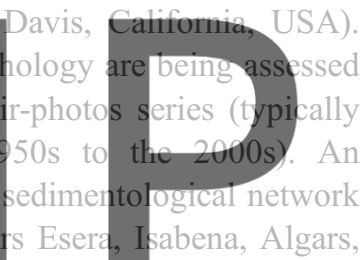

Ribera Salada, and Cabriel) are also being set up; sites are

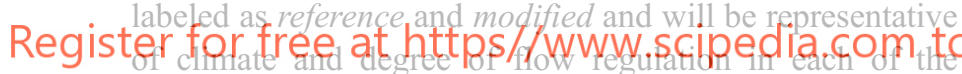
basins. Impacts on channel and riparian corridor are also

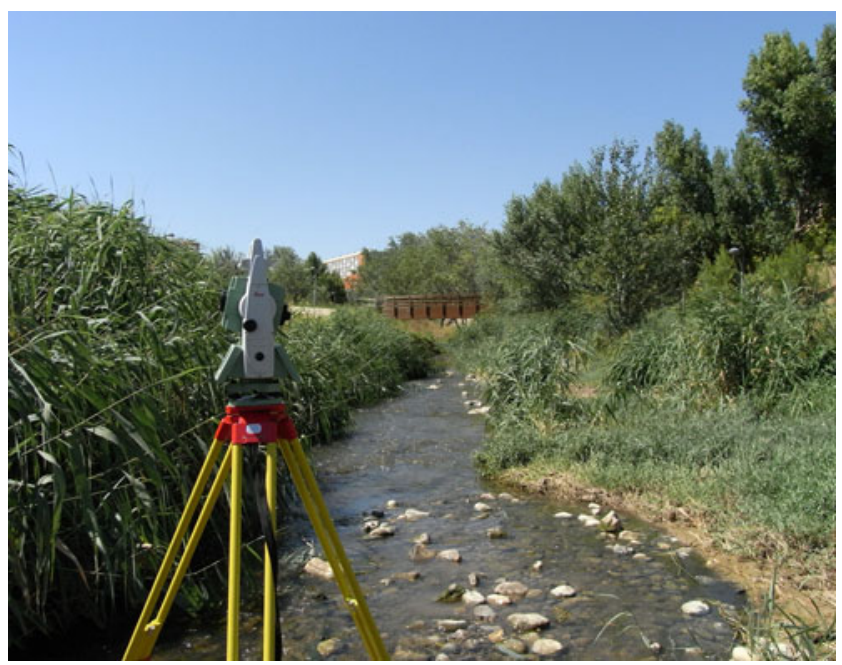

Fig. 5 Example of a monitoring site and ongoing fieldwork under the WP MORPH. (Site: River Huerva, Ebro Basin; date: June 15th, 2010; author: Jose A. López-Tarazón) assessed during field surveys including impacts on longitudinal and lateral connectivity (e.g., dams, dykes, riprap, weirs, culverts, and other man-made structures), artificial changes in channel planform and adjustments of the riverbed (i.e., degradation/aggradation) as well as other impacts (e.g., sewers, water abstraction, and evidences of gravel mining). Finally, the composition, structure, and dynamism of both channel and riparian vegetation were assessed considering longitudinal and lateral connectivity. This was done combining field techniques and analysis of aerial photographs. Present surveys and photographs will be compared with historic aerial photographs to measure changes in channel dimensions and cover of riparian areas during the last decades. A database including sediment transport, channel sediment structure, and physical habitat characteristics of the study sites is also being elaborated. In particular, WP MORPH includes the generation of detailed sediment transport series; they will be the bases for a better understanding of the link between microscale and mesoscale riverchannel processes as well as to couple them with the long-term hydrological modeling.

Within WP4 QUALITY the first extensive sampling campaign has been undertaken. A total of 77 samples of

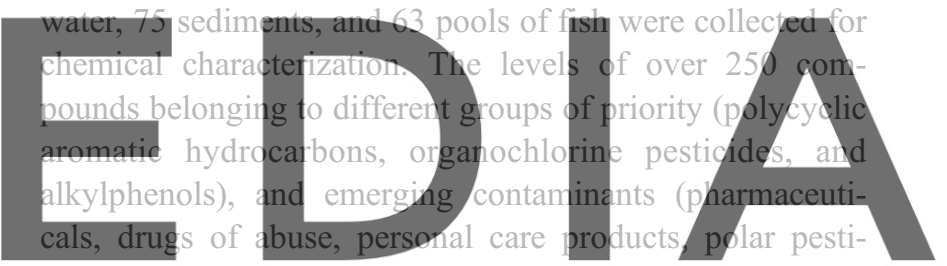

cides, perfluorinated compounds, endocrine disrupting compqunds, halogenated. flame retardants, and nanopardewesload the version without the waterkark

analytical techniques based on gas chromatographytandem mass spectrometry and liquid chromatographytandem and hybrid mass spectrometry. Current work also involves a deep revision of the already existing methodologies and development and validation of methods for routine monitoring of these contaminants in different types of matrices (water, suspended solids, sediment, and biota). The developed methods are addressed to solve the drawbacks and pitfalls of those already in use, to improve the quality control and to ensure a reliable, high throughput, and low-cost monitoring.

Invertebrate community has been sampled in each basin along a toxicity gradient. The habitat (fine sediment) and sites were the same that those sampled for chemical characterization in order to find potential relationships between compounds concentration and organisms. The parameters analyzed in invertebrate community are: density, biomass, species composition, and biochemical markers (concentration of lipids and oxidative enzymes). Estimations of environmental risk in the studied basins for invertebrates are obtained with a treatment of historical 
data (water agencies) of priority compounds and biological indexes.

First results regarding loads and distribution of pharmaceuticals in the Ebro river basin shows that the spatial distribution is affected by the river flow at each sampling point and corresponding dilution factor, resulting in higher concentrations and higher loads in small tributaries than in the Ebro River (Fig. 6). The study showed that some compounds are preferentially found bound to suspended solids (Fig. 7) and not detected in river water. Compounds with basic characteristics ( $\mathrm{pKa}>7$ ) showed higher tendency to remain in suspended solids. For example, famotidine, timolol, and nadolol, all with $\mathrm{pKa}>9$ were not detected in surface water. On the other hand, diazepam, gemfibrozil, and naproxen $(\mathrm{pKa}<5)$ were only detected in surface water. The sediment samples generally presented lower concentrations than suspended solids. The highest concentrations obtained in sediments were for acetaminophen, mevastatin, and tylosin A and rarely exceeded $200 \mathrm{ng} \mathrm{g}^{-1}$.

WP PROCESS has followed a twofold track. First, in an attempt to gather some summary data on river ecosystem processes across multiple sites, experiments on decompo- sition of organic matter (poplar tongue depressors) have been performed at all 77 reaches included in the project. The results will be analyzed by multivariate statistics to discern the main environmental factors governing wood breakdown in wet years, and the experiment repeated in the future, in dryer conditions, at least at some key sites. On the second hand, the dataset gathered by water agencies is being analyzed to screen sites with a good potential to estimate whole river metabolism based on continuous monitoring of oxygen, temperature, and discharge, based on the classic single site, open-channel method (Odum 1956; Izagirre et al. 2008). These sites will be studied in detail, and historical data will be used to define the response of river metabolism to environmental stress, as, for instance, comparing metabolism in wet and dry periods (Fig. 8).

WP UPSCALE has performed the implementation of external models for dynamic (slope and riparian) vegetation (Quevedo and Francés 2008) and inorganic nitrogen (Medici et al. 2010) into the TETIS-SCARCE. It is worth to highlight that the process-oriented model TETIS-SCARCE is distributed in space to cope all the natural spatial variability of the
Fig. 6 Total aqueous (dissolved) concentration of 80 studied pharmaceuticals in the Ebro river basin (sampling sites R0-R20 are in the Ebro river from the source to the mouth; sampling sites T2-T16 in the tributaries; figure prepared by B. Ferreira)

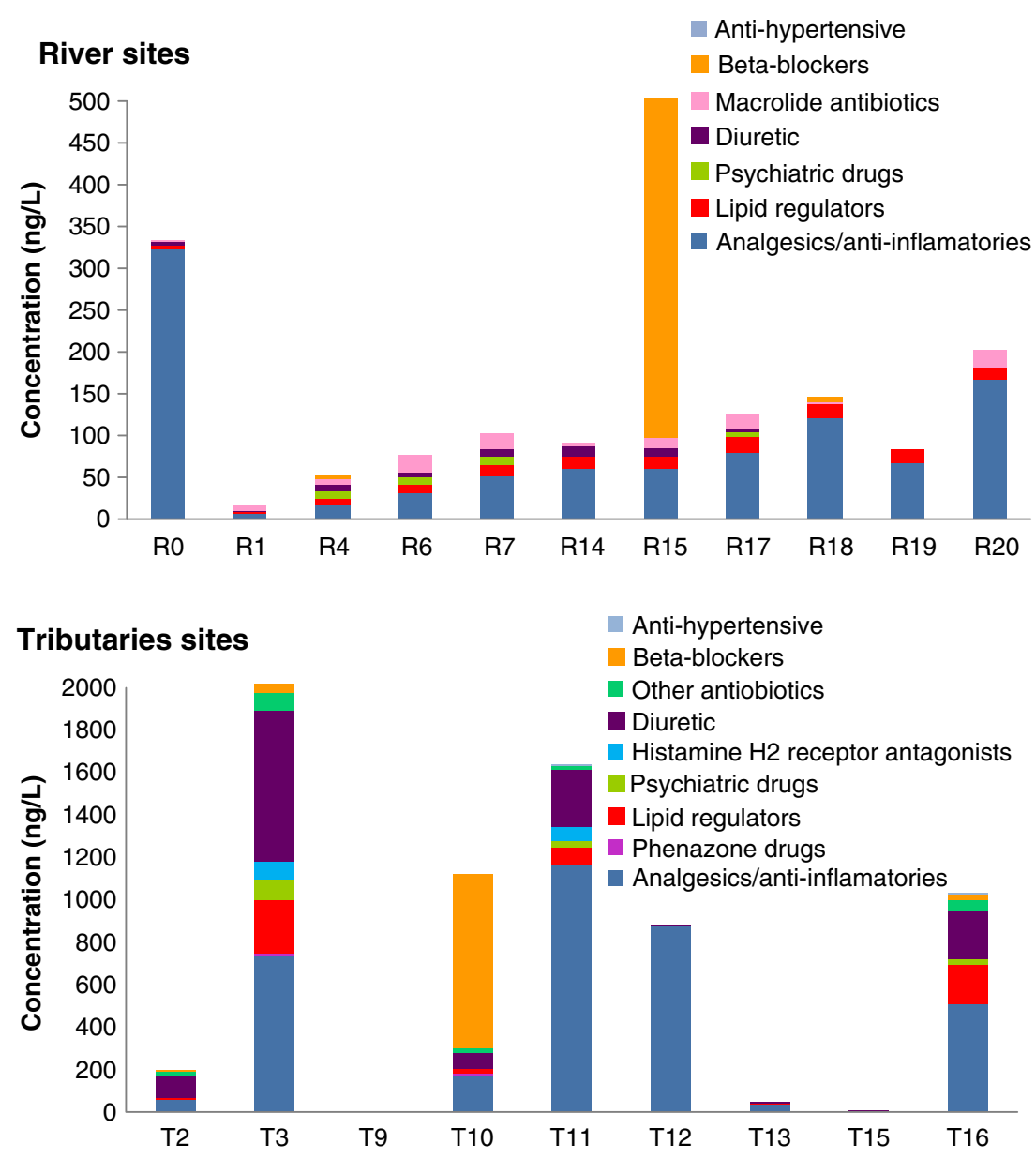


Fig. 7 Distribution

of individual pharmaceuticals between aqueous phase $(R W)$ and suspended solids $(S S)$ in water samples from the Ebro river basin (figure prepared by B. Ferreira)

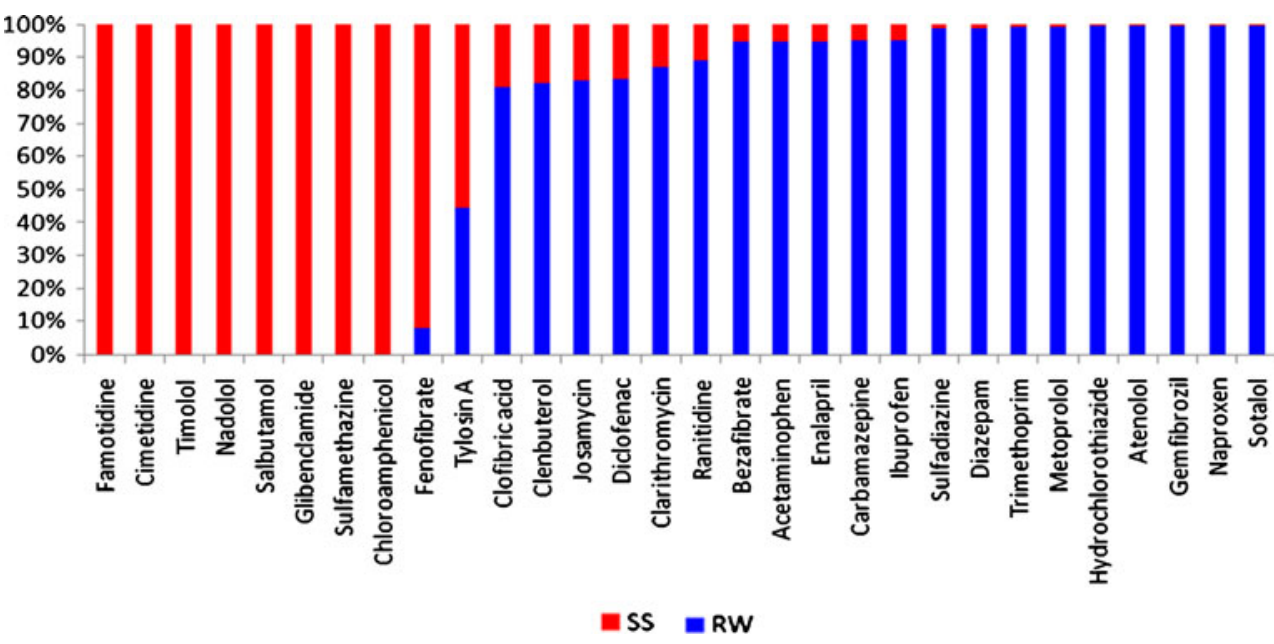

water cycle and its associated processes within the catchment. However, in spite of all the attempts that have been made in the past, it is still difficult to establish an optimum spatial subdivision modeling that provides the best performance for a distributed hydrological model. To face this issue, the spatial discretization of the TETIS model effective parameters (as far, the static storage capacity parameter $H_{\mathrm{u}}$
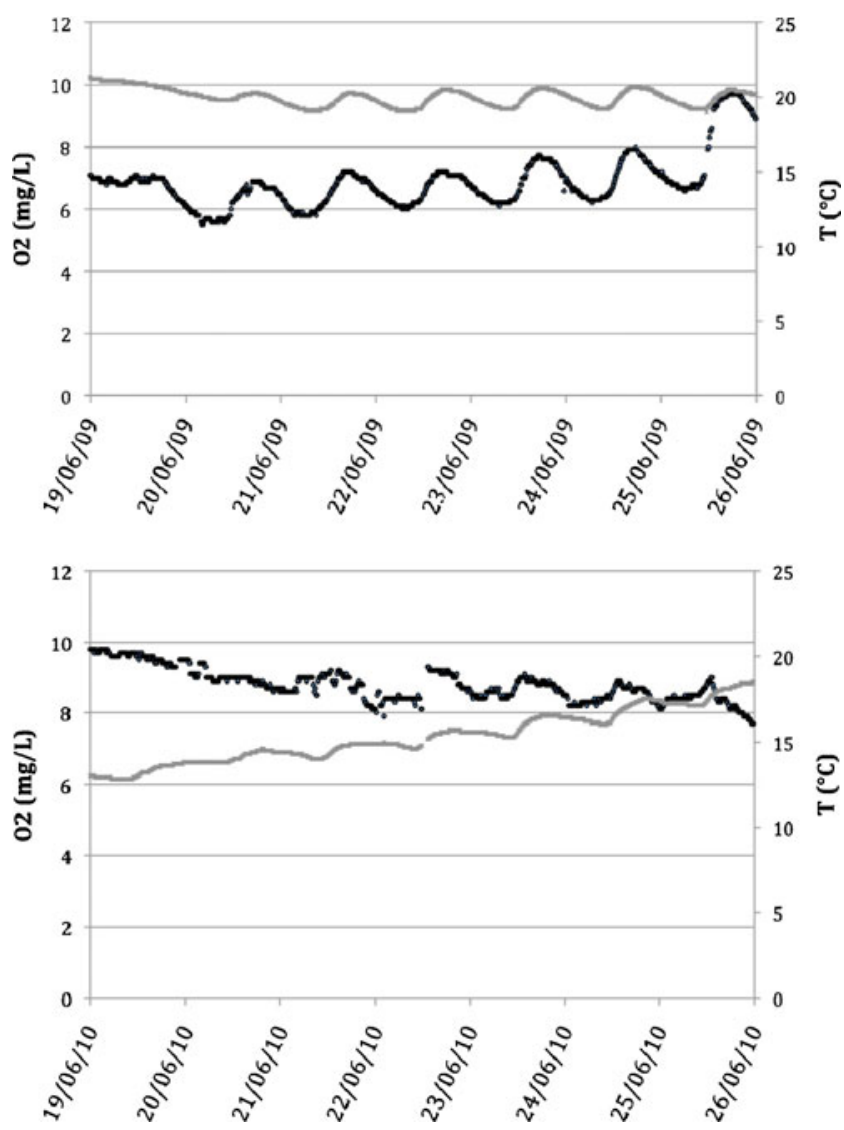

Fig. 8 Dynamics of temperature (gray line) and oxygen (black dots) at river Zadorra (Ebro basin), measured every 10 min during 1 week in June, in two contrasting years. Left, drier year $2009\left(Q=3.6 \mathrm{~m}^{3} \mathrm{~s}^{-1}\right)$; right, wetter year $2010\left(Q=8.1 \mathrm{~m}^{3} \mathrm{~s}^{-1}\right)$. River flow has a great impact on ecosystem metabolism and effective saturated hydraulic conductivity parameter $k_{\mathrm{s}}$ ) has been analyzed as well as its implications for the definition of a critical cell size. Moreover, also the importance of soil parameters sub-grid heterogeneities representation has been tested in terms of model performance improvement (Barrios et al. 2010). The rainfall-runoff model TETIS has already been applied to the Jucar river basin, obtaining satisfactory results for both calibration and validation processes (Ramos-Fernández and Francés 2010). The new data being collected within the WP DATA for the Jucar basin will certainly help to achieve better estimated parameter maps for the future TETIS-SCARCE model, obtaining also improved and more robust calibration results.

The work performed in WP ECONOMY depends on the results obtained by the other WPs. For this reason, the activities of this WP in the first year of SCARCE project are restricted to the conceptual approach that will be used in the future. This approach considers that incidence of climate change on human well-being depends on: (1) the impact of this phenomenon on the ecosystems, (2) the state of ecosystems for being able to cope with external disturbances and (3) which ecosystems services are required with more or less intensity by society. Addressing this issue in the horizon of 2050 shows that there is a significant room for articulating alternative societal responses to increase ecosystem's adaptative abilities. It is also possible to vary social well-being standards in order to maintain or even create socio-ecosystems' resilience (Walker et al. 2002) against the effects of climate change on water ecosystem. Exploring, anticipating, and building-up socio-ecosystems resilient pathways require the contribution of an extended peer community, beyond the scientific community as it is necessary to deal with complexity, ignorance, uncertainty, and risk of irreversibility (Funtowicz and Ravetz 1994). In order to tackle this explorative and transitional challenge, participative-scenario methods have been identified as 
useful tools (Kay et al. 1999; Walker et al. 2002). In this WP, participative scenarios will be adopted aiming a double orientation: futures exploration and transitional pathways identification.

WP SERVICES has started the development and adaptation of the InVEST software to the Llobregat basin, which was selected as a pilot basin to adapt the model to the Mediterranean conditions. So far, the data needed to run the model was gathered and first simulations on a reduced set of services were performed. One example is the first estimation of the service "water provisioning" at the Llobregat basin (Fig. 9). This service has been calculated using the terrestrial module of InVEST at a spatial resolution of $30 \times 30 \mathrm{~m}$ and considering mainly precipitation, evapotranspiration, and human demand. In this sense, the services water provisioning, waste treatment, and sediment retention were selected among the whole set of considered services to be used in the developing phase of the model. During this initial phase, new modules are being developed to complement the current InVEST version. Thus, a module on the role of in-stream processes is developed, as well as modules for the calibration and sensitivity analyses. These analyses can help to reduce uncertainty in method operation and determine the stability of its outputs by illustrating the impact of introducing changes to specific input parameters. The tool allows evaluating and checking model appropriateness to the problem, promoting a better understanding of the model outcomes. The development of these new modules is performed by members from different institutions that participate in SCARCE, as well as by the InVEST

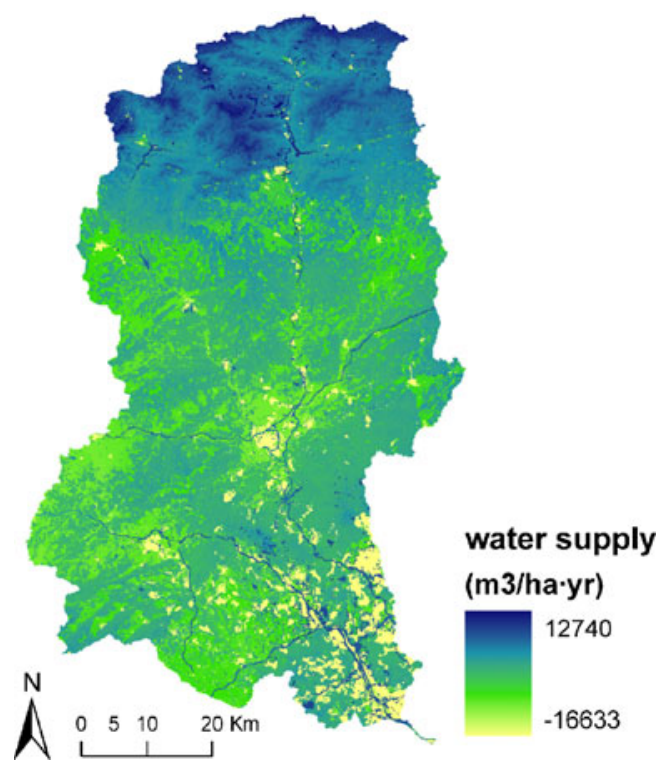

Fig. 9 Water provisioning service in the Llobregat basin $\left(\mathrm{m}^{3} \mathrm{ha}^{-1}\right.$ year $\left.^{-1}\right)$, calculated with the terrestrial module of InVEST at the spatial resolution of $30 \times 30 \mathrm{~m}$ developers from the Stanford University. Furthermore, WP SERVICES has been involved with members from WP MORPH, QUALITY, and PROCESS in the definition of river reaches for the characterization of in-stream processes as a function of the most important abiotic factors (e.g., hydrology, canalization, regulation by reservoirs, water pollution, and water abstraction).

WP FRAME has developed several activities related to the communications of the objectives and the strategy of the project to the river basins management authorities and endusers. Thus, several meetings were maintained with the Water Agencies from Andalusian and Catalonian and with other authorities/agencies of the river basins (Confederaciones hidrográficas del Guadalquivir, Júcar, and Ebro). A wide number of researchers, end-users, stakeholders, and management authorities participated in the kick-off meeting of the project, which was held in Barcelona in April 2010, showing a high interest for the objectives of the project and providing significant feedbacks for updating the research needs at basin level. The collaboration activities between members of the SCARCE project and the water/agencies authorities have continued during the first year of the project by delivering data to gather relevant existing knowledge for all basins, as it has been mentioned previously in WP DATA, and participating in different events. Thus, in the First SCARCE Annual Conference "Understanding effects of global change on water quantity and quality in river basins" held in Girona in December 2010, there was active participation. A survey will be submitted to management authorities, policy makers, stakeholders, and end-users to identify the knowledge that is necessary to generate new scientific management tools.

Additional project activities have included various specialist meetings (Kick-off meeting: Barcelona, 7 April 2010; 1st SCARCE annual conference; Girona, 2-3 December 2010), the publication of internal reports and international peer-reviewed manuscripts (Barceló and Sabater 2010; Boix et al. 2010; Elosegi et al. 2010; García-Galán et al. 2010a; García-Galán et al. 2010b; Gaudes et al. 2010; Guerra et al. 2010; Kuster et al. 2010a; Kuster et al. 2010b; López-Serna et al. 2010; Llorca et al. 2010; Marcé et al. 2010; Mas-Martí et al. 2010; Paredes et al. 2010; Petrovic et al. 2010; Puy-Azurmendi et al. 2010; Ricart et al. 2010a; Ricart et al. 2010b; SánchezVila et al. 2010; Stevenson and Sabater 2010; Tornés and Sabater 2010; Vázquez-Roig et al. 2010; Ylla et al. 2010; Barahona-Palomo et al. 2011; Carmona-Catot et al. 2011; Fernàndez-Garcia and Sánchez-Vila 2011; Jelic et al. 2011; Köck-Schulmeyer et al. 2011; Ramos-Jiliberto et al. 2011) and the organization of training courses: "Structural and functional responses of river ecosystems to multiple stressors" (Bilbao, 21-22 October 2010) and "Analysis, fate and risks of organic contaminants in river basins under 
water scarcity" (Valencia, 7-8 February 2011). This is complemented by a series of press releases and public newspaper appearances.

\section{Final remarks}

SCARCE aims to bring together a large group of researchers, stakeholders, and policy makers across a wide range of disciplines to understand the relevance of water scarcity in river functions. This challenge is met by communication tools including an Internet Platform for data Exchange but also many scientific meetings among the various groups. The structure of SCARCE into work packages allows sharing responsibilities between researchers who are specialists in their respective fields. The work performed by the different workpackages expands through different scales, starting from the monitoring and modeling studies to the river basin scale. This goal has been set from the very beginning of the project by the fundamental objective to provide the foundations for an improved understanding of the effects of the global change on water availability, water quality, and ecosystem services and economy.

Acknowledgemnts This work has been supported by the Spanish Ministry of Science and Innovation through the project ConsoliderIngenio 2010 CSD2009-00065. Special thanks are due to all partners of the SCARCE consortium and the peer review panel for ensuring quality results and fruitful collaboration within the project.

\section{References}

Andreu J, Capilla J, Sanchís E (1996) AQUATOOL, a generalized decision-support system for water-resources planning and operational management. J Hydrol 177:269-291

Barahona-Palomo M, Riva M, Sánchez-Vila X, Vázquez-Sune E, Guadagnini A (2011) Quantitative comparison of impellerflowmeter and particle-size-distribution techniques for the characterization of hydraulic conductivity variability. Hydrogeology Journal 19:603-612

Barceló D, Petrovic M (eds) (2011) The Ebro River basin. the handbook of environmental chemistry. Springer, Berlin

Barceló D, Sabater S (2010) Water quality and assessment under scarcity: prospects and challenges in Mediterranean watersheds. $\mathrm{J}$ Hydrol 383:1-4

Barrios M, Orozco J, López F, Francés F (2010). Influencia de momentos de segundo orden en el escalamiento espacial de parámetros hidrológicos. In: XXIV Congreso Latinoamericano de Hidráulica, Punta del Este, Uruguay

Boix D, García-Berthou E, Gascón S, Benejam L, Tornés E, Sala J, Benito J, Munné A, Solà C, Sabater S (2010) Response of community structure to sustained drought in Mediterranean rivers. J Hydrol 383:135-146

Bolster D, Barahona M, Dentz M, Fernàndez-Garcia D, Sánchez-Vila X, Trinchero P, Valhondo C, Tartakovsky DM (2009) Probabilistic risk analysis of groundwater remediation strategies. Water Resour Res 45: W06413
Brack W, Bakker J, de Deckere E, Deerenberg C, van Gils J, Hein M, Jurajda P, Kooijman B, Lamoree M, Lek S, López de Alda MJ, Marcomini A, Muñoz I, Rattei S, Segner H, Thomas K, von der Ohe PC, Westrich B, de Zwart D, Schmitt-Jansen M (2005) MODELKEY - Models for assessing and forecasting the impact of environmental key pollutants on freshwater and marine ecosystems and biodiversity. Environ Sci Pollut Res $12: 252-256$

Calbó J (2010) Water scarcity in the Mediterranean. In: Sabater S, Barceló D (eds) The handbook of environmental chemistry. Springer, Berlin

Carmona-Catot G, Benito J, García-Berthou E (2011) Comparing latitudinal and upstream-downstream gradients: life history traits of invasive mosquitofish. Divers Distrib 17:214-224

CHE (2008) Confederación Hidrográfica del Ebro. Available from: http://www.chebro.es. Accessed January 2009

de Barros FPJ, Bolster D, Sanchez-Vila X, Nowak W (2011) A divide and conquer approach to cope with uncertainty, human health risk and decision making in contaminant hydrology. Water Resour Res (in press)

Dodds WK, Bouska WW, Eitzmann JL, Pilger TJ, Pitts KL, Riley AJ, Schloesser JT, Thornbrugh DJ (2009) Eutrophication of US freshwaters: analysis of potential economic damages. Environ Sci Technol 43:12-19

Elosegi A, Díez J, Mutz M (2010) Effects of hydromorphological integrity on biodiversity and functioning of river ecosystems. Hydrobiologia 657:199-215

Estrela T, Fidalgo A, Fullana J, Maestu J, Pérez MA, Pujante AM (2004) Júcar Pilot River Basin. Provisional article 5. Report pursuant to the Water Framework Directive. Confederación Hidrográfica del Júcar, Valencia (Spain). p 208

Fernàndez-Garcia D, Sánchez-Vila X (2011) Optimal reconstruction of concentrations, gradients and reaction rates from particle distributions. J Contam Hydrol 120-121:99-114

Fernàndez-Garcia D, Sánchez-Vila X, Illangasekare TH (2002) Convergent-flow tracer tests in heterogeneous media: combined experimental-numerical analysis for determination of equivalent transport parameters. J Contam Hydrol 57:129-145

Francés F, Vélez JI, Vélez JJ (2007) Split-parameter structure for the automatic calibration of distributed hydrological models. J Hydrol 332:226-240

Funtowicz S, Ravetz J (1994) The worth of a songbird: ecological economics as a post-normal science. Ecol Econ 10:197-207

García-Galán M, Garrido T, Fraile J, Ginebreda A, Díaz-Cruz M, Barceló D (2010a) Application of fully automated online solid phase extraction-liquid chromatography-electrospray-tandem mass spectrometry for the determination of sulfonamides and their acetylated metabolites in groundwater. Anal Bioanal Chem 399:795-806

García-Galán MJ, Díaz-Cruz MS, Barceló D (2010b) Occurrence of sulfonamide residues along the Ebro river basin: removal in wastewater treatment plants and environmental impact assessment. Environ Int 37:462-473

Gasith A, Resh VH (1999) Streams in Mediterranean climate regions: abiotic influences and biotic responses to predictable seasonal events. Annu Rev Ecol Syst 30:51-81

Gaudes A, Artigas J, Muñoz I (2010) Species traits and resilience of meiofauna to floods and drought in a Mediterranean stream. Mar Freshw Res 61:1336-1347

Ginebreda A, Muñoz I, López de Alda MJ, Brix R, López-Doval J, Barceló D (2010) Environmental risk assessment of pharmaceuticals in rivers: relationships between hazard indexes and aquatic macroinvertebrate diversity indexes in the Llobregat River (NE Spain). Environ Int 36:153-162

Giorgi F, Lionello P (2008) Climate change projections for the Mediterranean region. Glob Planet Chang 63:90-104 
Greskowiak J, Prommer H, Massmann G, Johnston CD, Nutzmann G, Pekdeger A (2005) The impact of variably saturated conditions on hydrogeochemical changes during artificial recharge of groundwater. Appl Geochem 20:1409-1426

Guasch H, Leira M, Montuelle B, Geiszinger A, Roulier JL, Tornés E, Serra A (2009) Use of multivariate analyses to investigate the contribution of metal pollution to diatom species composition: search for the most appropriate cases and explanatory variables. Hydrobiologia 627:143-158

Guerra P, Eljarrat E, Barceló D (2010) Simultaneous determination of hexabromocyclododecane, tetrabromobisphenol $\mathrm{A}$, and related compounds in sewage sludge and sediment samples from Ebro River basin (Spain). Anal Bioanal Chem 397:2817-2824

IPCC (2007) Fourth assessment report: climate change 2007. Cambridge University Press, Cambridge

Izagirre O, Agirre U, Bermejo M, Pozo J, Elosegi A (2008) Environmental controls of whole-stream metabolism identified from continuous monitoring of Basque streams. J N Am Benthol Soc 27:252-268

Jelic A, Gros M, Ginebreda A, Céspedes-Sánchez R, Ventura F, Petrovic M, Barceló D (2011) Occurrence, partition and removal of pharmaceuticals in sewage water and sludge during wastewater treatment. Water Res 45:1165-1176

Kay JJ, Regier HA, Boyle M, Francis G (1999) An ecosystem approach for sustainability: addressing the chanllenge of complexity. Futures 31:721-742

Köck-Schulmeyer M, Ginebreda A, Postigo C, López-Serna R, Pérez S, Brix R, Llorca M, López de Alda MJ, Petrovic M, Munné A, Tirapu L, Barceló D (2011) Wastewater reuse in Mediterranean semi-arid areas: the impact of discharges of tertiary treated sewage on the load of polar micro pollutants in the Llobregat river (NE Spain). Chemosphere 82:670-678

Kuster M, De la Cal A, Eljarrat E, López de Alda MJ, Barceló D (2010a) Evaluation of two aquatic passive sampling configurations for their suitability in the analysis of estrogens in water. Talanta 83:493-499

Kuster M, Díaz-Cruz S, Rosell M, López de Alda MJ, Barceló D (2010b) Fate of selected pesticides, estrogens, progestogens and volatile organic compounds during artificial aquifer recharge using surface waters. Chemosphere 79:880-886

Lacorte S, Raldúa D, Martínez E, Navarro A, Díez S, Bayona JM, Barceló D (2006) Pilot survey of a broad range of priority pollutants in sediment and fish from the Ebro river basin (NE Spain). Environ Pollut 140:471-482

Lindenmayer DB, Likens GE (2009) Adaptive monitoring: a new paradigm for long-term research and monitoring. Trends Ecol Evol 24:482-486

López-Serna R, Pérez S, Ginebreda A, Petrovic M, Barceló D (2010) Fully automated determination of 74 pharmaceuticals in environmental and waste waters by online solid phase extraction-liquid chromatography-electrospray-tandem mass spectrometry. Talanta $83: 410-424$

Llorca M, Farré M, Picó Y, Barceló D (2010) Study of the performance of three LC-MS/MS platforms for analysis of perfluorinated compounds. Anal Bioanal Chem 398:1145-1159

Marcé R, Rodríguez MA, García JC, Armengol J (2010) El Nino Southern oscillation and climate trends impact reservoir water quality. Glob Chang Biol 16:2857-2865

Martín G, Toja J, Sala SE, Fernández MD, Reyes I, Casco MA (2010) Application of diatom biotic indices in the Guadalquivir River Basin, a Mediterranean basin. Which one is the most appropriated? Environ Monit Assess 170:519-534

Mas-Martí E, García-Berthou E, Sabater S, Tomanova S, Muñoz I (2010) Comparing fish assemblages and trophic ecology of permanent and intermittent reaches in a Mediterranean stream. Hydrobiologia 657:167-180
Medici C, Bernal S, Butturini A, Sabater F, Martín M, Wade AJ, Francés F (2010) Modelling the inorganic nitrogen behaviour in a small Mediterranean forested catchment, Fuirosos (Catalonia). Hydrol Earth Syst Sci 14:223-237

Millenium Ecosystem Assessment (2005) Ecosystems and human well-being: synthesis. Island Press, Washington (US), p 137

Muñoz I, López-Doval JC, Ricart M, Villagrasa M, Brix R, Geiszinger A, Ginebreda A, Guasch H, López de Alda MJ, Romaní AM, Sabater S, Barceló D (2009) Bridging levels of pharmaceuticals in river water with biological community structure in the Llobregat River Basin (Northeast Spain). Environ Toxicol Chem 28:2706-2714

Nadal M, Kumar V, Schuhmacher M, Domingo JL (2008) Applicability of a neuroprobabilistic integral risk index for the environmental management of polluted areas: a case study. Risk Anal 28:271-286

Navarro-Ortega A, Tauler R, Lacorte S, Barceló D (2010) Occurrence and transport of PAHs, pesticides and alkylphenols in sediment samples along the Ebro River Basin. J Hydrol 383:5-17

Navarro A, Lacorte S, Barceló D (2010) Occurrence and transport of pesticides and alkylphenols in water samples along the Ebro River Basin. J Hydrol 383:18-29

Navarro A, Tauler R, Lacorte S, Barceló D (2006) Chemometrical investigation of the presence and distribution of organochlorine and polyaromatic compounds in sediments of the Ebro River Basin. Anal Bioanal Chem 385:1020-1030

Nelson E, Mendoza G, Regetz J, Polasky S, Tallis H, Cameron DR, Chan KMA, Daily GC, Goldstein J, Kareiva PM, Lonsdorf E, Naidoo R, Ricketts TH, Shaw MR (2009) Modeling multiple ecosystem services, biodiversity conservation, commodity production, and tradeoffs at landscape scales. Front Ecol Environ 7:4-11

Nilsson C, Reidy CA, Dynesius M, Revenga C (2005) Fragmentation and flow regulation of the world's large river systems. Science 308:405-408

Odum HT (1956) Primary production in flowing waters. Limnol Oceanogr 1:102-117

Paredes-Arquiola J, Andreu-Álvarez J, Martín-Monerris M, Solera A (2010) Water quantity and quality models applied to the Jucar River Basin, Spain. Water Res Manag 24:2759-2779

Paredes J, Andreu J, Solera A (2010) A decision support system for water quality issues in the Manzanares River (Madrid, Spain). Sci Total Environ 408:2576-2589

Petrovic M, Farré M, López de Alda MJ, Perez S, Postigo C, Kock M, Radjenovic J, Gros M, Barceló D (2010) Recent trends in the liquid chromatography-mass spectrometry analysis of organic contaminants in environmental samples. J Chromatogr A 1217:4004-4017

Puy-Azurmendi E, Navarro A, Olivares A, Fernandes D, Martínez E, López de Alda MJ, Porte C, Cajaraville MP, Barceló D, Piña B (2010) Origin and distribution of polycyclic aromatic hydrocarbon pollution in sediment and fish from the biosphere reserve of Urdaibai (Bay of Biscay, Basque country, Spain). Mar Environ Res 70:142-149

Quevedo DI, Francés F (2008) A conceptual dynamic vegetation-soil model for arid and semiarid zones. Hydrol Earth Syst Sci 12:1175-1187

Ramos-Fernández L, Francés F (2010). Utilidad de la precipitación obtenida por satélite en la modelación hidrológica aplicada a la cuenca del río. In: XXIV Congreso Latinoamericano de Hidráulica, Punta del Este, Uruguay

Ramos-Jiliberto R, Valdovinos FS, Arias J, Alcaraz C, García-Berthou E (2011) A network-based approach to the analysis of ontogenetic diet shifts: an example with an endangered, small-sized fish. Ecol Complex 8:123-129

Ricart M, Guasch H, Alberch M, Barceló D, Bonnineau C, Geiszinger A, Farré M, Ferrer J, Ricciardi F, Romaní AM, Morin S, Proia L, 
Sala L, Sureda D, Sabater S (2010a) Triclosan persistence through wastewater treatment plants and its potential toxic effects on river biofilms. Aquat Toxicol 100:346-353

Ricart M, Guasch H, Barceló D, Brix R, Conceicao MH, Geiszinger A, López de Alda MJ, Lopez-Doval JC, Munoz I, Postigo C, Romani AM, Villagrasa M, Sabater S (2010b) Primary and complex stressors in polluted mediterranean rivers: pesticide effects on biological communities. J Hydrol 383:52-61

Sabater S, Tockner K (2010) Effects of hydrologic alterations on the ecological quality of river ecosystems. In: Sabater S, Barceló D (eds) Water scarcity in the Mediterranean. Springer, Berlin

Sánchez-Vila X, Carrera J (1997) Directional effects on convergent flow tracer tests. Math Geol 29:551-569

Sánchez-Vila X, Fernàndez-Garcia D, Guadagnini A (2010) Interpretation of column experiments of transport of solutes undergoing an irreversible bimolecular reaction using a continuum approximation. Water Resour Res 46:W12510

Sand-Jensen K, Pedersen NL (2005) Differences in temperature, organic carbon and oxygen consumption among lowland streams. Freshw Biol 50:1927-1937

Schroter D, Cramer W, Leemans R, Prentice IC, Araujo MB, Arnell NW, Bondeau A, Bugmann H, Carter TR, Gracia CA, de la Vega-Leinert AC, Erhard M, Ewert F, Glendining M, House JI, Kankaanpaa S, Klein RJT, Lavorel S, Lindner M, Metzger MJ, Meyer J, Mitchell TD, Reginster I, Rounsevell M, Sabate S, Sitch S, Smith B, Smith J, Smith P, Sykes MT, Thonicke K, Thuiller W, Tuck G, Zaehle S, Zierl B (2005) Ecosystem service supply and vulnerability to global change in Europe. Science 310:1333-1337

Singer MB, Dunne T (2001) Identifying eroding and depositional reaches of valley by analysis of suspended sediment transport in the Sacramento River, California. Water Resour Res 37:3371-3381
Stevenson RJ, Sabater S (2010) Understanding effects of global change on river ecosystems: science to support policy in a changing world. Hydrobiologia 657:3-18

Tharme RE (2003) A global perspective on environmental flow assessment: emerging trends in the development and application of environmental flow methodologies for rivers. River Res Appl 19:397-441

Tornés E, Sabater S (2010) Variable discharge alters habitat suitability for benthic algae and cyanobacteria in a forested Mediterranean stream. Mar Freshw Res 61:441-450

Trinchero P, Sánchez-Vila X, Fernàndez-Garcia D (2008) Point-topoint connectivity, an abstract concept or a key issue for risk assessment studies? Adv Water Res 31:1742-1753

Vázquez-Roig P, Andreu V, Blasco C, Picó Y, Andreu V (2010) SPE and LC-MS/MS determination of 14 illicit drugs in surface waters from the Natural Park of L'Albufera (ValSncia, Spain). Anal Bioanal Chem 397:2851-2864

Vericat D, Batalla RJ (2006) Sediment transport in a large impounded river: the lower Ebro, NE Iberian Peninsula. Geomorphology 79:72-92

Walker B, Carpenter S, Anderies J, Abel N, Cumming G, Janssen M, Lebel L, Norberg J, Peterson GD, Pritchard R (2002) Resilience management in social-ecological systems: a working hypothesis for a participatory approach. Conserv Ecol 6:14

Weyhenmeyer GA (2004) Synchrony in relationships between the North Atlantic Oscillation and water chemistry among Sweden's largest lakes. Limnol Oceanogr 49:1191-1201

Ylla I, Sanpera-Calbet I, Vázquez E, Romaní AM, Muñoz I, Butturini A, Sabater S (2010) Organic matter availability during pre- and post-drought periods in a Mediterranean stream. Hydrobiologia 657:217-232 